\title{
Analysis of Parking Space Requirements in Grand Galaxy Park Mall and Performance of Boulevard Raya Roads Jakasetia, Bekasi City
}

\author{
Widodo Budi Dermawan and Alif Imamsyah \\ Faculty of Engineering, Mercu Buana University Jakarta, Indonesia \\ wbdermawan@gmail.com, alif.imamsyah76@gmail.com
}

\begin{abstract}
Bekasi City is a large city with a population of $2,803,283$ people (BPS, 2016). The area of Bekasi City is 210.49 $\mathrm{km}^{2}$. Grand Galaxy Park Mall is one of the malls located in the city of Bekasi precisely on Boulevard Raya Roads Grand Galaxy City Jakasetia. The area is of land approximately 19.000 meters $^{2}$ with a floor area of 17.000 meters $^{2}$ which consists of 5 floors. Grand Galaxy Park Mall became one of the popular shopping centers because this mall is known as a modern mall and was built with an environmentally friendly concept and the location of this mall is also very strategic and integrated with the residential area of Grand Galaxy City, Schools, Shops and Offices. The method used in this research is the observation method. The Observation Method is a method by conducting direct survey of spaciousness. This is absolutely necessary to determine the actual condition. The survey method used in this analysis is the method of recording the number of vehicles. The largest accumulation of parking for cars on Saturday as many as 132 vehicles occurred between 18.00-18.59 WIB, while for motorcycles on Saturday as many as 167 vehicles occurred between 19.00-19.59 WIB. The average duration of vehicle parking is 3 hours 42 minutes for cars and 3 hours 30 minutes for motorbikes. The largest parking index is $85.16 \%$ for cars occurred on Saturday at 18.00-18.59 WIB and 41.75 for motorcycles occurred on Saturday at 19.00-19.59 WIB. The biggest Parking Turn Over is 4 vehicles / SRP / observation time for cars and 3 vehicles / SRP / observation time for motorcycles and that happens on Saturdays. Judging from the analysis of the Jalan Raya Raya Boulevard Jalan Jakasetia for the survey speed at peak hours in the morning, afternoon and evening get the level of service or Level of Service (LOS), namely B and C.
\end{abstract}

Keywords: Parking Index, parking requirements, Level of Service, Grand Galaxy Park Mall.

\section{Introduction}

Bekasi City is a large city with a population of 2,803,283 people (BPS, 2016). The area of Bekasi City is $210.49 \mathrm{~km}^{2}$. Bekasi is also a buffer city of the capital city of Jakarta, where it has to accommodate several public facilities, due to the dense city of Jakarta. So, it can't be denied that many developers are now making the city of Bekasi as a business destination, with its many apartment, housing and shopping centers. Increasing population and activities have increased the complexity of transportation problems. One of the problems is the need to provide parking spaces in shopping centers that continue to grow.

The same thing happened to the Grand Galaxy Park Mall on the Boulevard Raya Grand Galaxy City, Bekasi City. Grand Galaxy Park Mall became one of the popular shopping centers because this mall is known as a modern mall and was built with an environmentally friendly concept and the location of this mall is also very strategic and integrated with the housing area of Grand Galaxy City, Schools, Shops and Offices .

The formulation of the problems in this study include: 1). What is the existing parking space capacity and whether the need for parking spaces at Grand Galaxy Park Mall, is now sufficient to meet the vehicle? 2). What are the characteristics of parking in the form of parking volume, parking accumulation, parking index, parking duration and turn-over at Grand Galaxy Park Mall Jakasetia, Bekasi City? 3). What are the alternative solutions in overcoming the problem of parking at Grand Galaxy Park Mall Jakasetia, Bekasi City? 4). What is the performance of the road in front of Grand Galaxy Park Mall Jakasetia, Bekasi City?

\section{Methodology}

\subsection{Data Collection Methods}

a) Observations or field observations include various matters relating to observations of physical conditions and activities at the study site. 


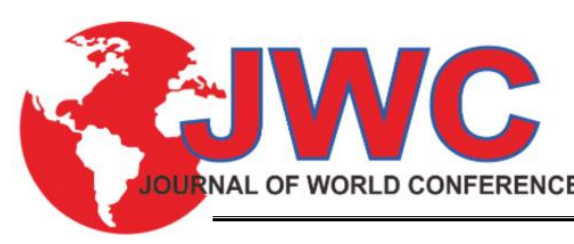

VOLUME 2 | NUMBER 2 | MARCH 2020

Available online at http://proceedings.worldconference.id.

ISSN: 2656-1174 (online)

b) Documentation is the activity of collecting and reviewing some information from periodicals, books, document literature, photographs, newspapers, electronic media and statistical references.

\subsection{Data Processing Methods and Data Analysis}

Data processing and data analysis methods used in this study are qualitative descriptive analysis by taking into account the results of the field survey regarding the duration of parking, accumulation, parking volume, parking capacity, parking index, parking space usage and parking space requirements. In addition, standards and guidelines for planning and operating parking facilities are also used. As for the performance of road sections by taking into account the results of the field survey regarding traffic volume data, side barriers data, road capacity (C) and Q / C ratio, speed of traffic survey results, speed based on MKJI 1997, and Level of Service (Level of Service).

\section{Results and Analysis}

\subsection{Parking Characteristics}

\subsubsection{Parking Accumulation}

Parking accumulation is the number of vehicles that are in a parking lot at a specified time interval and divided according to the type of purpose of travel, where the integration of the accumulated parking during a certain period shows the parking load (number of parking vehicles) in units of vehicle hours per specified time period.

Table 1. Car and Motorcycle Parking Accumulation

Friday December 6, 2019 and Saturday December 7, 2019

\begin{tabular}{ccccc}
\hline \multirow{2}{*}{ Class Time } & \multicolumn{2}{c}{ Car Accumulation } & \multicolumn{2}{c}{ Motorcyle Accumulation } \\
\cline { 2 - 5 } & $\begin{array}{c}\text { Friday } \\
\text { December 6, 2019 }\end{array}$ & $\begin{array}{c}\text { Saturday } \\
\text { December 7, 2019 }\end{array}$ & $\begin{array}{c}\text { Friday } \\
\text { December 6, 2019 }\end{array}$ & $\begin{array}{c}\text { Saturday } \\
\text { December 7, 2019 }\end{array}$ \\
\hline $\mathbf{1 1 0 . 0 0}$ & 4 & 5 & 12 & 20 \\
$\mathbf{1 0 . 0 0}-\mathbf{1 0 . 5 9}$ & 6 & 6 & 20 & 30 \\
$\mathbf{1 1 : 0 0}-\mathbf{1 1 . 5 9}$ & 22 & 15 & 53 & 54 \\
$\mathbf{1 2 . 0 0}-\mathbf{1 2 . 5 9}$ & 18 & 19 & 55 & 46 \\
$\mathbf{1 3 . 0 0}-\mathbf{1 3 . 5 9}$ & 37 & 16 & 64 & 65 \\
$\mathbf{1 4 : 0 0}-\mathbf{1 4 . 5 9}$ & 28 & 26 & 74 & 77 \\
$\mathbf{1 5 . 0 0}-\mathbf{1 5 . 5 9}$ & 23 & 62 & 51 & 66 \\
$\mathbf{1 6 . 0 0}-\mathbf{1 6 . 5 9}$ & 30 & 87 & 70 & 61 \\
$\mathbf{1 7 . 0 0}-\mathbf{1 7 . 5 9}$ & 44 & 103 & 74 & 121 \\
$\mathbf{1 8 . 0 0}-\mathbf{1 8 . 5 9}$ & 51 & 132 & 87 & 158 \\
$\mathbf{1 9 . 0 0}-\mathbf{1 9 . 5 9}$ & 31 & 91 & 81 & 167 \\
$\mathbf{2 0 . 0 0}-\mathbf{2 0 . 5 9}$ & 9 & 46 & 56 & 87 \\
$\mathbf{2 1 . 0 0}-\mathbf{2 1 . 5 9}$ & 0 & 0 & 0 & 0 \\
$>\mathbf{2 2 . 0 0}$ & 0 & 0 & 0 & 0 \\
\hline
\end{tabular}

Source: Author's Process, 2019

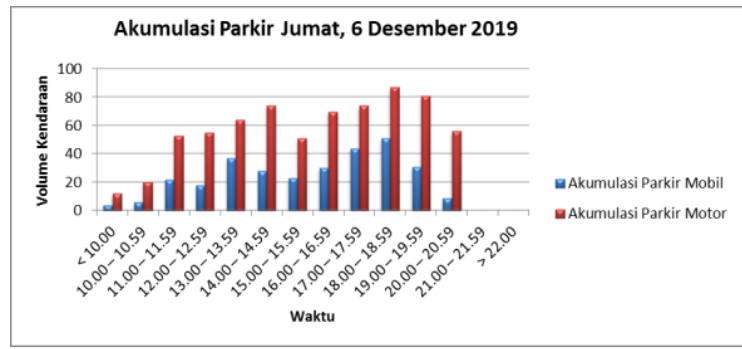

Figure 1. Graph Accumulated Parking Car and Motorcycle Friday December 6, 2019

Source: Author's Process, 2019 


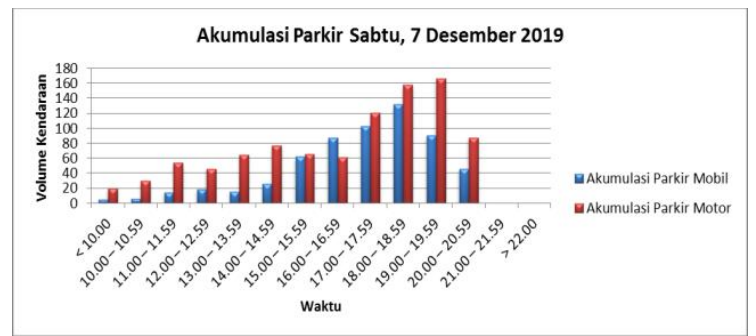

Figure 2. Graph Accumulated Parking Car and Motorcycle Saturday December 7, 2019

Source: Author's Process, 2019

\subsubsection{Parking Index}

The parking index is a comparison between the accumulation of vehicles parked with the available parking capacity. This parking index is used to determine whether or not the number of parking plots available at the study site is suitable for accommodating vehicles parked.

Table 2 . Car and Motorcycle Parking Index

Friday December 6, 2019 and Saturday December 7, 2019

\begin{tabular}{ccccc}
\hline \multirow{2}{*}{ Class Time } & \multicolumn{2}{c}{ Car Parking Index } & \multicolumn{2}{c}{ Motorcycle Parking Index } \\
\cline { 2 - 5 } & $\begin{array}{c}\text { Friday } \\
\text { December 6, 2019 }\end{array}$ & $\begin{array}{c}\text { Saturday } \\
\text { December 7, 2019 }\end{array}$ & $\begin{array}{c}\text { Friday } \\
\text { December 6, 2019 }\end{array}$ & $\begin{array}{c}\text { Saturday } \\
\text { December 7, 2019 }\end{array}$ \\
\hline$<10.00$ & $2.58 \%$ & $3.23 \%$ & $3.00 \%$ & $5.00 \%$ \\
$10.00-10.59$ & $3.87 \%$ & $3.87 \%$ & $5.00 \%$ & $7.50 \%$ \\
$11: 00-11.59$ & $14.19 \%$ & $9.68 \%$ & $13.25 \%$ & $13.50 \%$ \\
$12.00-12.59$ & $11.61 \%$ & $12.26 \%$ & $13.75 \%$ & $11.50 \%$ \\
$13.00-13.59$ & $23.87 \%$ & $10.32 \%$ & $16.00 \%$ & $16.25 \%$ \\
$14: 00-14.59$ & $18.06 \%$ & $16.77 \%$ & $18.50 \%$ & $19.25 \%$ \\
$15.00-15.59$ & $14.84 \%$ & $40.00 \%$ & $12.75 \%$ & $16.50 \%$ \\
$16.00-16.59$ & $19.35 \%$ & $56.13 \%$ & $17.50 \%$ & $15.25 \%$ \\
$17.00-17.59$ & $28.39 \%$ & $66.45 \%$ & $18.50 \%$ & $30.25 \%$ \\
$18.00-18.59$ & $32.90 \%$ & $85.16 \%$ & $21.75 \%$ & $39.50 \%$ \\
$19.00-19.59$ & $20.00 \%$ & $58.71 \%$ & $20.25 \%$ & $41.75 \%$ \\
$20.00-20.59$ & $5.81 \%$ & $29.68 \%$ & $14.00 \%$ & $21.75 \%$ \\
$21.00-21.59$ & $0.00 \%$ & $0.00 \%$ & $0.00 \%$ & $0.00 \%$ \\
$>22.00$ & $0.00 \%$ & $0.00 \%$ & $0.00 \%$ & $0.00 \%$ \\
\hline
\end{tabular}

Source: Author's Process, 2019

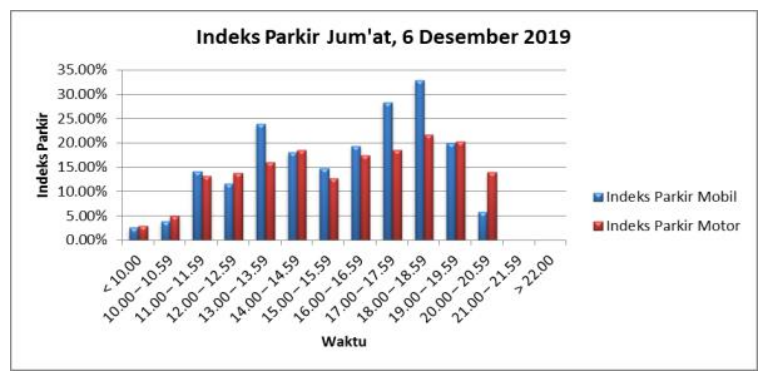

Figure 3. Graph Index Parking Car and Motorcycle Friday December 6, 2019

Source: Author's Process, 2019 


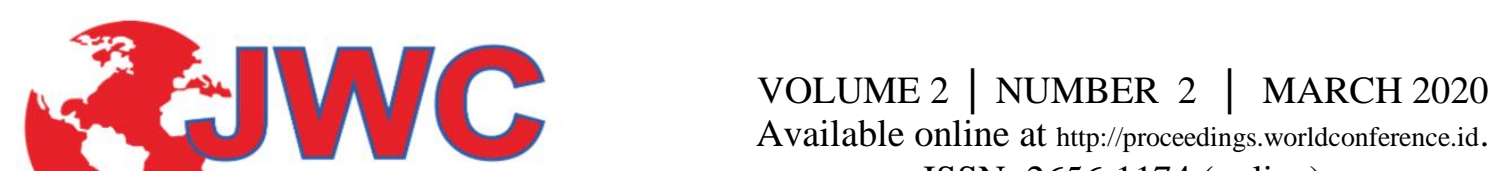

Available online at http://proceedings.worldconference.id.

ISSN: 2656-1174 (online)

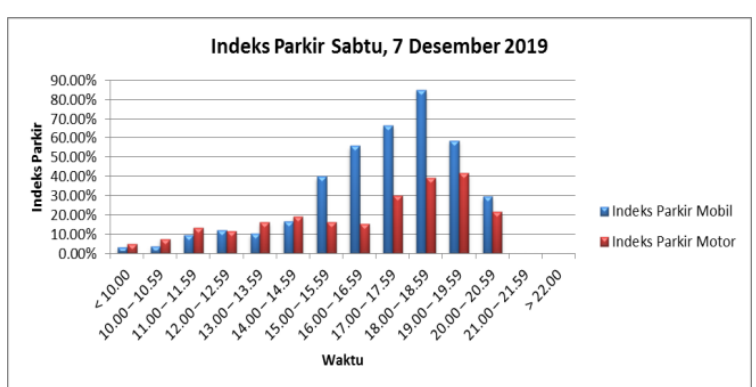

Figure 4. Graph Index Parking Car and Motorcycle Saturday December 7, 2019

Source: Author's Process, 2019

\subsubsection{Analysis of Parking Space Needs for the Next 5 (Five) Years}

To determine the need for parking spaces in the Grand Galaxy Park Mall in the next 5 years, the influential variable is economic growth in the city of Bekasi. Based on data from the Central Statistics Agency (BPS) of Bekasi City, the average economic growth rate of $5.8 \%$ per year, while the largest volume of cars and motor vehicles used by the volume in 2019. This figure can be used to estimate how long the parking space cars and motorbike parking spaces Grand Galaxy Park Mall can accommodate the number of vehicle volumes each year.

a) Car Vehicle

\section{Estimated Growth Center $=$ Accumulated Vehicles $(1+\text { Growth })^{\text {n }}$}

Highest vehicle accumulation in $2019=132$ vehicles

Available car parking spaces $=155$ SRP

Estimated parking growth $\quad=132 \times(1+0.058)^{5}$

$=132 \times 1.3$

$=172$

So, the accumulation of automobiles in 2024 is expected to increase to 172 vehicles.

b) Motorcycle Vehicles

The highest accumulation of motor vehicles in $2019=167$ vehicles

Available motorcycle parking spaces $=400 \mathrm{SRP}$

Estimated parking growth $\quad=167 \times(1+0.058)^{5}$

$=167 \times 1.3$

$=221$

Thus, the accumulation of automobiles in 2024 is expected to increase to 218 vehicles.

Table 3. Estimated Car Parking Accumulation

\begin{tabular}{ccccc}
\hline \multirow{2}{*}{$\begin{array}{c}\text { Year of } \\
\text { Prediction }\end{array}$} & $\begin{array}{c}\text { Car } \\
\text { Estimated } \\
\text { Parking Index }\end{array}$ & $\begin{array}{c}\text { Estimated Vehicle } \\
\text { Parking Accumulation }\end{array}$ & $\begin{array}{c}\text { Estimated } \\
\text { Parking Index }\end{array}$ & $\begin{array}{c}\text { Estimated Vehicle } \\
\text { Parking Accumulation }\end{array}$ \\
\hline 2020 & $90.32 \%$ & 140 & $44.25 \%$ & 177 \\
2021 & $95.48 \%$ & 148 & $46.75 \%$ & 187 \\
2022 & $101.29 \%$ & 157 & $49.50 \%$ & 198 \\
2023 & $107.11 \%$ & 166 & $52.25 \%$ & 209 \\
2024 & $110.97 \%$ & 172 & $55.25 \%$ & 221 \\
\hline
\end{tabular}

Source: Author's Process, 2019

\subsection{Roads}

\subsubsection{Traffic Volume}

Traffic data is obtained from field survey results during rush hour by counting the number of vehicles every 15 minutes for 2 hours in the morning, 15 minutes for 2 hours in the afternoon, and 15 minutes for 2 hours in the afternoon. The number of vehicles is converted into passenger car units (pcu) according to the type of vehicle that passes Jalan Boulevard Raya . 


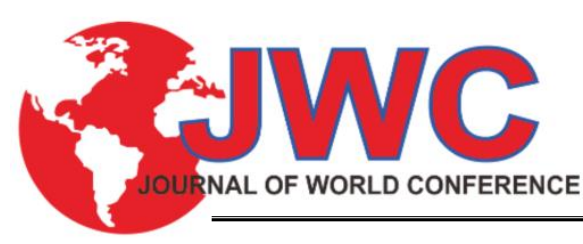

VOLUME 2 | NUMBER 2 | MARCH 2020

Available online at http://proceedings.worldconference.id.

ISSN: 2656-1174 (online)

Table 4. Maximum Vehicle Traffic Volume

\begin{tabular}{lcccc}
\hline \multirow{2}{*}{ Period } & \multicolumn{2}{c}{ Friday December 6, 2019 } & \multicolumn{2}{c}{ Saturday December 7, 2019 } \\
\cline { 2 - 5 } & kend / hour & smp / hour & kend / hour & smp / hour \\
\hline Morning $(7.00-9.00)$ & 2646 & 1612.1 & 1372 & 788.8 \\
Afternoon $(11.00-13.00)$ & 2848 & 1847.6 & 2967 & 1676.0 \\
Evening $(16.00-18.00)$ & 3650 & 2227.6 & 3643 & 2198.3 \\
\hline
\end{tabular}

Source: Author's Process, 2019

\subsubsection{Side Barriers}

The side obstacle data is obtained from the results of the field survey during rush hour by counting the number of side barriers every 15 minutes for 2 hours in the morning, 15 minutes for 2 hours in the afternoon, and 15 minutes for 2 hours in the afternoon.

Table 5. Maximum Volume of Constraints

\begin{tabular}{lcccc}
\hline \multirow{2}{*}{\multicolumn{1}{c}{ Period }} & \multicolumn{2}{c}{ Friday December 6, 2019 } & \multicolumn{2}{c}{ Saturday December 7, 2019 } \\
\cline { 2 - 5 } & kend /hour & smp/hour & kend / hour & smp /hour \\
\hline Morning (7.00-9.00) & 138 & 101.0 & 289 & 206.6 \\
Afternoon (11.00-13.00) & 482 & 314.7 & 497 & 352.5 \\
Evening (16.00-18.00) & 464 & 316.9 & 621 & 428.9 \\
\hline
\end{tabular}

Source: Author's Process, 2019

\subsubsection{Road Capacity (C) \& Q / C Ratio}

The capacity of an urban road can be determined from the formula as follows:

$\mathrm{C}=\mathrm{Co} \times \mathrm{FCw} \times \mathrm{FCsp} \times \mathrm{FCsf} \times \mathrm{FCcs}$

Where :

$\mathrm{C}=$ Capacity (smp/hour)

Co = base capacity (smp/hour)

$\mathrm{FCw}=$ Lane width adjustment factor

FCsp = Directional separator adjustment factor

FCsf $=$ Side drag adjustment factor

FCcs = City size adjustment factor

Then the value of $\mathrm{C}$ ratio can be known by calculation as follows:

$\begin{array}{ll}\mathbf{C} & =\mathbf{C o} \times \mathbf{F C w} \times \mathbf{F C s p} \times \mathbf{F C s f} \times \mathbf{F C c s} \\ \mathrm{C} & =3300 \times 0.92 \times 1.00 \times 0.86 \times 1.00 \\ \mathrm{C} & =2610,9 \mathrm{smp} / \text { hour }\end{array}$

Table 6. Capacity of Jalan Boulevard Raya

\begin{tabular}{ccccc}
\hline \multirow{2}{*}{ Variable } & \multicolumn{4}{c}{ Boulevard Raya Roads } \\
\cline { 2 - 5 } & Adjustment Factor & Morning & Noon & Afternoon \\
\hline Co & Divided Road (2 lanes) / 1 direction & 3300 & 3300 & 3300 \\
FCw & The road is divided into 3 m width & 0.92 & 0.92 & 0.92 \\
FCsp & The road is divided in one direction & 1 & 1 & 1 \\
FCsf & Medium Side Barriers (M), Effective Width & .86 & .86 & .86 \\
& of Sidewalks 1 m, Road Divided 2/1 & & 1 & 1 \\
FCcs & Total Population of Bekasi City is 2,803,283 & 1 & & \\
& Million & 2610,9 & 2610,9 & 2610,9 \\
\hline
\end{tabular}

Source: Author's Process, 2019 


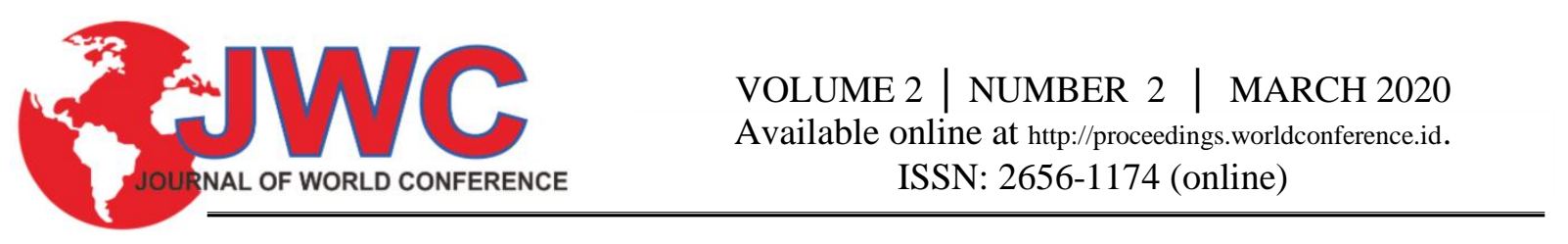

Table 7. Q / C Ratio of Jalan Boulevard Raya Section on Friday December 6, 2019

\begin{tabular}{lcccc}
\hline \multirow{2}{*}{\multicolumn{1}{c}{ Period }} & \multicolumn{4}{c}{ Friday December 6, 2019 } \\
\cline { 2 - 5 } & $\mathbf{Q}$ & $\mathbf{C}$ & $\mathbf{Q} / \mathbf{C}$ & LOS \\
\hline Morning (7.00-9.00) & 1612.1 & 2610,9 & 0.62 & $\mathrm{~B}$ \\
Afternoon $(11.00-13.00)$ & 1847,6 & 2610,9 & 0.71 & $\mathrm{C}$ \\
Evening $(16.00-18.00)$ & 2227,6 & 2610,9 & 0.85 & $\mathrm{D}$ \\
\hline
\end{tabular}

Source: Author's Process, 2019

Table 8. Q / C Ratio of Jalan Boulevard Raya Section on Saturday December 7, 2019

\begin{tabular}{lcccc}
\hline \multirow{2}{*}{ Period } & \multicolumn{4}{c}{ Saturday December 7, 2019 } \\
\cline { 2 - 5 } & $\mathbf{Q}$ & $\mathbf{C}$ & $\mathbf{Q} / \mathbf{C}$ & LOS \\
\hline Morning $(7.00-9.00)$ & 788,8 & 2610,9 & 0.30 & $\mathrm{~A}$ \\
Afternoon $(11.00-13.00)$ & 1676.0 & 2610,9 & 0.64 & $\mathrm{~B}$ \\
Evening $(16.00-18.00)$ & 2198.3 & 2610,9 & .84 & $\mathrm{D}$ \\
\hline
\end{tabular}

Source: Author's Process, 2019

\subsubsection{Speed of Traffic Survey Results}

Following the complete traffic speed survey data at peak hours on each section, the results of primary data collection in the field can be seen in the calculation of the average speed based on a sample of 3 light vehicles / 15 minutes unless there is an error data (values that are too different).

Table 9. Speed Resume

\begin{tabular}{lcccc}
\hline \multicolumn{5}{c}{ Boulevard Raya Roads } \\
& \multicolumn{1}{c}{ Friday } & & \\
& Specember 6, 2019 & Saturday December 7, 2019 \\
& 41.58 & LOS & Speed & LOS \\
\hline Morning $(7.00-9.00)$ & 39.11 & $\mathrm{~B}$ & 45.16 & $\mathrm{~B}$ \\
Afternoon $(11.00-13.00)$ & 35.08 & $\mathrm{C}$ & 41.24 & $\mathrm{~B}$ \\
Evening $(16.00-18.00)$ & $\mathrm{C}$ & 34.64 & $\mathrm{C}$ \\
\hline
\end{tabular}

\section{Conclusions}

Source: Author's Process, 2019

Based on the survey results and analysis of parking characteristics at the Grand Galaxy Park Mall in the previous discussion, the following results are obtained:

1. Available capacity and Parking Space Needs based on the Director General of Land Transportation at Grand Galaxy Park Mall.

a) Number of car parking entrances and exits, namely:

1) 2 entrance car parking areas.

2) 2 exit car parking areas.

b) Number of motorized parking entrances and exits, namely:

1) 1 entrance to the motorcycle parking area.

2) 1 exit for the motorcycle parking area.

c) The size of the Parking Space Unit (SRP) for cars in Grand Galaxy Park Mall has a dimension of $2.50 \mathrm{x}$ 4.50 (90\% of BSLLAK 1998) with a total capacity of 155 SRP.

d) The size of the Parking Space Unit (SRP) for motorcycles in the Grand Galaxy Park Mall has dimensions of $0.75 \times 1.75$ (87.5\% of BSLLAK 1998) with a total capacity of 400 SRP

e) Minimum parking space requirements according to the Director General of Land Transportation are 184 SRP and a maximum of 394 SRP.

2. Characteristics of Parking at Grand Galaxy Park Mall.

a) Vehicle volume

1) Friday, December 6, 2019 
Cars : $: 365$ vehicles

Motorcycle : 518 vehicles

2) Saturday, December 7, 2019

Cars : :547 vehicles

Motorcycle : 862 vehicles

b) Parking Accumulation

1) Friday, December 6, 2019

Cars $\quad: 51$ vehicles occurred between $18.00-18.59$

Motorcycles: 87 vehicles occurred between 18.00 - 18.59

2) Saturday December 7, 2019

Cars $\quad: 132$ vehicles occur between $18.00-18.59$

Motorcycles: 167 vehicles occurred between 19.00 - 19.59

c) Average Parking Duration

1) Friday, December 6, 2019

Car : The average duration of a car park is 3 hours 36 minutes.

Motorcycle : The average duration of motorcycle parking is 3 hours 18 minutes.

2) Saturday, December 7, 2019

Car : The average duration of a car park is 3 hours 42 minutes.

Motorcycle : The average duration of motorcycle parking is 3 hours 30 minutes.

So it is included in middle parkers .

d) Parking Index

1) Friday, December 6, 2019

Car $\quad$ : Parking index of $32.90 \%$ occurs at $18.00-18.59$

Motorcycles: The parking index of $21.75 \%$ occurs at $18.00-18.59$

2) Saturday, December 7, 2019

Car $\quad$ : The parking index of 85.16 occurs at $18.00-18.59$

Motorcycles: The parking index of $41.75 \%$ occurs at 19:00 - 19.59

3. An alternative solution to improve parking services, especially during peak hours, is the need to increase the number of parking officers so that circulation and order of the parking area is maintained, especially in the afternoon at 17:00 - 19:00 and parallel parking provided with traffic cones is enforced with the help of officers parking. Another solution is the addition of a parking availability sensor installed at the top of the parking space with a red pointer to fill the vehicle and a green pointer for an empty parking space. In addition it needs to be circumvented by raising parking fees. At this time, the Grand Galaxy Park Mall implement car parking rates Rp 6,000 and $\mathrm{Rp} \mathrm{4,000} \mathrm{next} \mathrm{hour} \mathrm{and} \mathrm{for} \mathrm{the} \mathrm{motor} \mathrm{tariff} \mathrm{of} \mathrm{Rp} 3.000$ and the next hour Rp 2000. Planning car

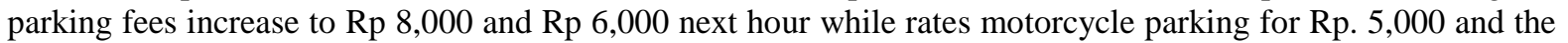
next hour Rp. 3000 . The plan is expected to be able to limit visitors to the duration of parking considering the high cost of parking fees.

4. Performance of Jalan Boulevard Raya

A. From the results of the analysis of Jalan Boulevard Raya Section that has been carried out:

1) Friday, December 6, 2019

a) Morning average service level or Level of Service (LOS) is B at 07.00 - 09.00 with a Saturation Degree value of 0.62 .

b) During the daytime the average level of service or Level of Service (LOS) is C at $11.00-13.00$ hours with a degree of saturation that is 0.71 .

c) In the afternoon the average level of service or Level of Service (LOS) is D at $16.00-18.00$ with a value of degree of saturation that is 0.85 .

2) Saturday, December 7, 2019

a) In the morning the average level of service or Level of Service (LOS) is A at $07.00-09.00$ with a Saturation Degree value of 0.30 .

b) During the daytime the average level of service or Level of Service (LOS) is B at $11.00-13.00$ with a saturation degree value of 0.64 .

c) In the afternoon the average level of service or Level of Service (LOS) is D at $16.00-18.00$ with a value of degree of saturation that is 0.84 .

B. Judging from the speed of the service level survey or Level of Service (LOS) on Jalan Raya Boulevard Section that has been carried out on: 
1) Friday, December 6, 2019

a) In the morning the level of service (LOS) is B.

b) Daytime service level or Level of Service (LOS) is C.

c) Evening service level or Level of Service (LOS) is C.

2) Saturday, December 7, 2019

a) In the morning the level of service (LOS) is B.

b) Daytime service level or Level of Service (LOS) is B.

c) In the afternoon service level or Level of Service (LOS) is C.

\section{Reference}

[1] Anonymously, (1993). Government Regulation No. 43 of 1993 concerning Road Infrastructure and Traffic, Jakarta.

[2] Anonymously, (1996) . Directorate General of Land Transportation . Guide . Technical Implementation of Parking Facilities . Jakarta.

[3] Anonymously, (1997). Indonesian Road Capacity Manual, Jakarta.

[4] BPS of the City of Bekasi. (2016). Bekasi City Regional Statistics 2016.

[5] Nurul Fahimmatul Habibah. (2019). Analysis of Parking Space Needs and Performance of Roads in Arion Mall Rawamangun, East Jakarta, Mercubuana University.

\section{Biography}

Widodo B. Dermawan is a Practitioner as well as a Lecturer in Civil Engineering, especially in the field of Transportation, he took Strata 1 at Parahyangan Catholic University, and took his Masters at the University of Wisconsin-Madison. In the world of education, he teaches at Mercu Buana University (Meruya), University of Indonesia (Depok).

Alif Imamsyah is a student of the Faculty of Civil Engineering at Mercu Buana University in 2015 and successfully completed his undergraduate education in February 2020. Mr. Alif Imamsyah was born in Bekasi August 31, 1994. $\mathrm{He}$ had worked in manufacturing companies namely PT Astra Honda Motor as an operator in the production division for 4 years, vocational education background with graduates Automotive Engineering in 2012. 